\title{
Porcine Enteritis Associated with Eimeria spinosa Henry, 1931 Infection
}

\author{
Author(s): David S. Lindsay, Regg Neiger, Michael Hildreth
}

Source: Journal of Parasitology, 88(6):1262-1263. 2002.

Published By: American Society of Parasitologists

DOI: http://dx.doi.org/10.1645/0022-3395(2002)088[1262:PEAWES]2.0.CO;2

URL: http://www.bioone.org/doi/full/10.1645/0022-3395\%282002\%29088\%5B1262\%3APEAWES

$\% 5 \mathrm{D} 2.0 . \mathrm{CO} \% 3 \mathrm{~B} 2$

BioOne (www.bioone.org) is a nonprofit, online aggregation of core research in the biological, ecological, and environmental sciences. BioOne provides a sustainable online platform for over 170 journals and books published by nonprofit societies, associations, museums, institutions, and presses.

Your use of this PDF, the BioOne Web site, and all posted and associated content indicates your acceptance of BioOne's Terms of Use, available at www.bioone.org/page/terms_of_use.

Usage of BioOne content is strictly limited to personal, educational, and non-commercial use. Commercial inquiries or rights and permissions requests should be directed to the individual publisher as copyright holder. 
American Society of Parasitology. David S. Lindsay, Regg Neiger, and Michael Hildreth (2002). "Porcine Enteritis Associated with

Eimeria spinosa Henry, 1931 Infection," Journal of Parasitology, Vol. 88, No. 6, pp. 1262-1263. doi: http://

dx.doi.org/10.1645/0022-3395(2002)088[1262:PEAWES]2.0.CO;2

1262 THE JOURNAL OF PARASITOLOGY, VOL. 88, NO. 6, DECEMBER 2002

J. Parasitol., 88(6), 2002, pp. 1262-1263

(C) American Society of Parasitologists 2002

\section{Porcine Enteritis Associated with Eimeria spinosa Henry, 1931 Infection}

David S. Lindsay, Regg Neiger*, and Michael Hildreth*, Center for Molecular Medicine and Infectious Diseases, Department of Biomedical Sciences and Pathobiology, Virginia-Maryland Regional College of Veterinary Medicine, Virginia Tech, 1410 Prices Fork Road, Blacksburg, Virginia 24061-0342. *Veterinary Science Department, Box 2175, South Dakota State University Brookings, South Dakota 57007-1396. e-mail: lindsayd@vt.edu

ABSTRACT: Coccidia of the genus Eimeria are present in most pigs raised on dirt in the United States. They are generally considered nonpathogenic in weaned pigs. Oocysts of Eimeria spinosa Henry, 1931 were observed in tissue sections and intestinal contents of a weaned male pig that died suddenly on a farm in Iowa. Microscopically, necrotizing enteritis associated with many thick-walled coccidial oocysts was present in intestinal sections. Examination of intestinal contents demonstrated oocysts that were thick-walled and had small projections on the surface of the oocyst wall, characteristic of E. spinosa Henry, 1931 of swine. Twenty-five oocysts in intestinal contents measured 20.4 by $14.2 \mu \mathrm{m}$. No pathogenic bacteria were detected in the pig by culture methods, but lesions suggestive of salmonellosis were observed in some tissues. The specific cause of death was not determined; however, $E$. spinosa infection was considered to have contributed to the death of this pig. The results suggest that E. spinosa may be pathogenic for pigs.

Coccidia of the genus Eimeria are common in swine raised on dirt or pasture in the United States (Vetterling, 1966; Greiner et al., 1982; Lindsay et al., 1984); however, intestinal disease in swine due to $\mathrm{Ei}$ meria spp. infection is not common (Hill et al., 1985). Eimeria spinosa was described by Henry (1931) from swine and is a member of the rough-walled group of porcine Eimeria species as later defined by Vetterling (1965). Koudela and Vitovec (1992) described the complete life cycle of E. spinosa and supplemented the previous experimental studies on this coccidium by Wiesenhütter (1962) and Ernst (1987). Because clinical porcine coccidiosis caused by Eimeria species is rare (Hill et al., 1985), we report coccidiosis caused by E. spinosa in a weaned pig from Iowa.

Fresh and formalin-fixed small intestine and intestinal contents were collected from a weaned male pig that died on a farm in Iowa. Samples were sent to and examined by diagnosticians at the Veterinary Science Department, South Dakota State University, Brookings, South Dakota. The submitting veterinarian described hemorrhage in the lung and necrosis in the ileum and jejunum. Several attempts to obtain additional clinical history from the veterinarian were unsuccessful. Examination of hematoxylin and eosin-stained histological sections indicated severe intestinal coccidiosis. Examination of intestinal contents revealed numerous rough-walled coccidial oocysts.

Intestinal sections demonstrated severe diffuse necrotizing enteritis characterized by necrosis of the luminal one-half to two-thirds of the mucosa. In some areas, necrosis extended to the submucosa (Fig. 1) There was extensive mucus accumulation in crypts and lumen with mild to moderate amounts of inflammation. Inflammatory cells were mostly mononuclear, with some eosinophils and lesser numbers of neutrophils. In some areas with deeper mucosal necrosis, there was thrombosis of blood vessels in the lamina propria. Mixed with the necrotic debris, mucus, and inflammatory cells of the lumen were large numbers of coccidial oocysts (Fig. 2). A variety of bacteria were present throughout mucosal lesions, suggesting opportunistic or postmortem overgrowth. Severity of changes in the submucosa varied directly with the severity of the lesions of corresponding luminal mucosa. They were characterized by congestion, thrombosis, and inflammatory cell accumulation. Inflammatory cells were the same as those found in the mucosa. There was moderate lymphoid cell depletion in Peyer's patches. The Peyer's patch domes had severe depletion, with necrosis of covering epithelium and large numbers of coccidia present. Crypt epithelium appeared to be herniated deep into muscularis mucosa, forming cysts partially lined by crypt epithelium and filled with mucus, necrotic debris, and many coccidia. Microscopic changes in sections of colon examined were much milder than in intestine; the most prominent change was thrombosis of blood vessels in the lamina propria and to a lesser extent in submucosa.
The superficial mucosa was autolytic, and its epithelium was missing. No coccidia were seen in the colon. Attempts were made to isolate bacteria from the fresh intestinal and colonic material. Aerobic bacterial cultures did not produce bacterial pathogens. Dark-field examinations of preparations were negative for bacterial pathogens.

Lesions in other tissues consisted of splenic congestion, multifocal hepatitis, and pulmonary thrombosis, which are suggestive of bacter-
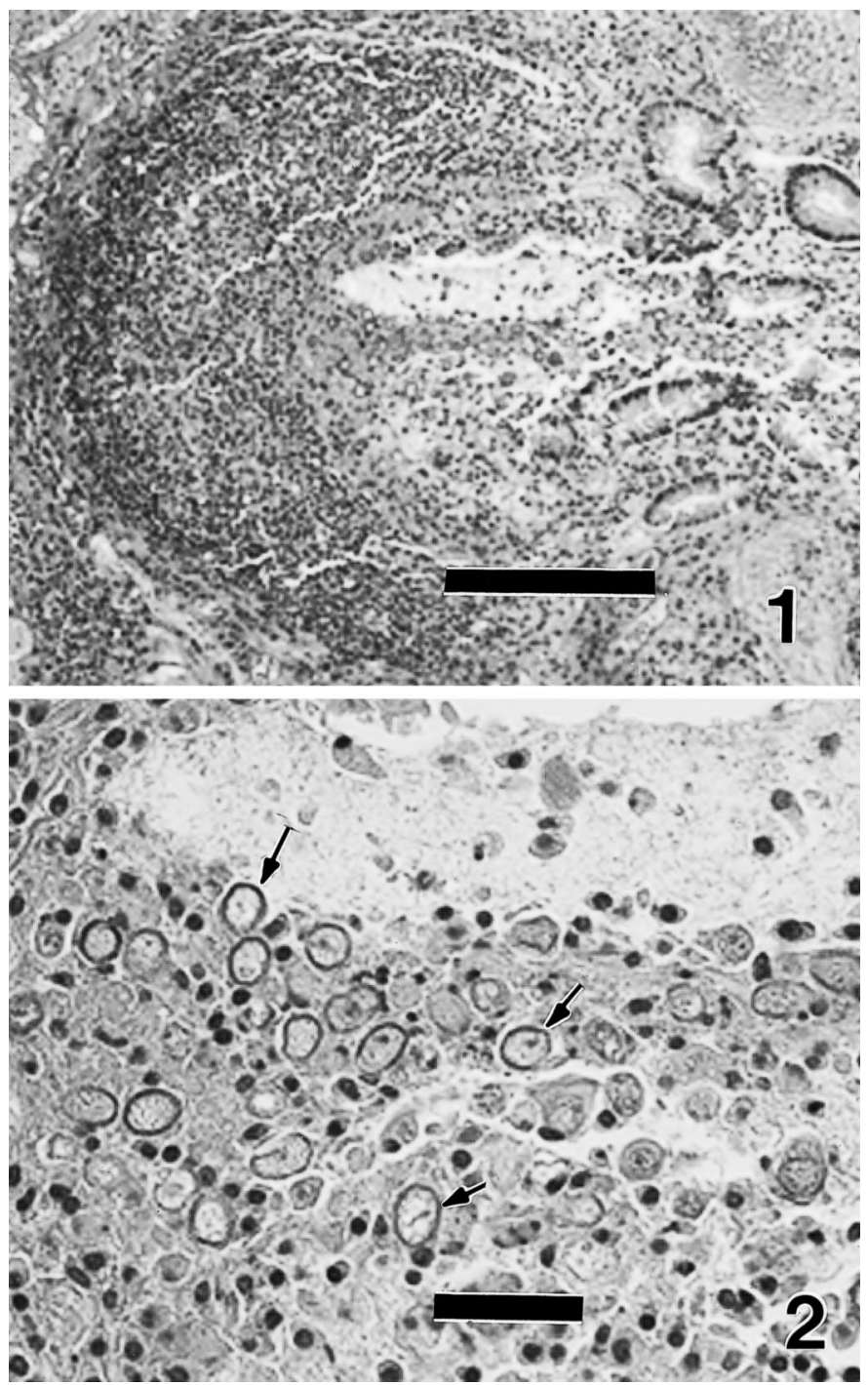

FIGURES 1-2. Lesions associated with Eimeria spinosa intestinal coccidiosis in a pig. 1. Low power in the region of Peyer's patches of the small intestine. There is necrosis of dome and follicular lymphocytes, with subsequent accumulation of necrotic debris, crypt epithelium, and coccidia. Destruction of the crypts is associated with numerous E. spinosa oocysts. Bar $=100 \mu \mathrm{m}$. 2. Higher power demonstrating thick-walled oocysts of E. spinosa (arrows). Bar $=50 \mu \mathrm{m}$. 


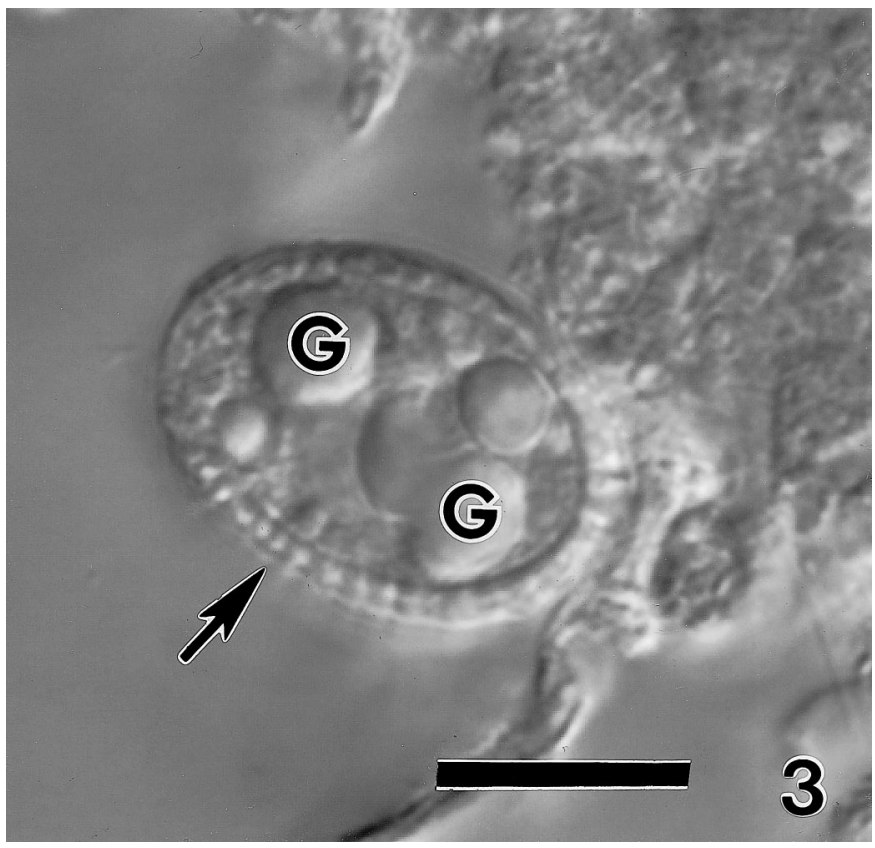

FIGURE 3. Oocyst of Eimeria spinosa from intestinal contents. Note the thick bilayered wall (arrow) and numerous globules (G). Bar $=10$ $\mu \mathrm{m}$.

emia, specifically the presence of Salmonella; however, attempts to culture bacterial pathogens from lung, liver, and spleen were negative.

Intestinal contents were stored in $2.5 \%(\mathrm{w} / \mathrm{v})$ potassium dichromate and sent to the Center for Molecular Medicine and Infectious Diseases, Department of Biomedical Sciences and Pathobiology, Virginia-Maryland Regional College of Veterinary Medicine, Virginia Tech, Blacksburg, Virginia, for morphological analysis. Oocysts $(n=25)$ were examined and photographed using an Olympus BX60 microscope equipped with differential contrast optics and a calibrated ocular micrometer.

No sporulated oocysts were observed. Oocysts had thick walls that contained spinelike projections (Fig. 3). The oocyst wall had 2 layers. Variable numbers of globules were present in the oocyst. The 25 oocysts measured $20.4 \pm 1.96$ by $14.2 \pm 1.96 \mu \mathrm{m}$ (range, $17-26$ by $12-16 \mu \mathrm{m}$ ).

Vetterling (1965) described the coccidia of swine present in the United States and placed E. spinosa in the rough-walled group. This group contains Eimeria perminuta Henry, 1931, Eimeria polita Pellérdy, 1949 (syn. Eimeria cerdonis Vetterling, 1965), and Eimeria scabra Henry, 1931. The oocysts of E. perminuta $(13.3$ by $11.7 \mu \mathrm{m})$ are much smaller than those of E. spinosa, and the oocysts of E. polita $(28.9$ by $21.3 \mu \mathrm{m})$ and E. scabra (31.9 by $22.5 \mu \mathrm{m})$ are much larger (Vetterling, 1965). Henry (1931) remarked that unsporulated E. spinosa oocysts contained large granules. In the present study, we described these as globules (Fig. 3).

Eimeria spinosa is generally considered nonpathogenic for pigs. Henry (1931) described E. spinosa from the cecal contents of a 5-mo-old pig that was clinically normal and from the cecum of a pig with enteritis. She did not describe microscopic lesions in these pigs. Wiesenhütter (1962) described clinical disease and death in a pig experimentally infected with $1.2 \times 10^{4} \mathrm{E}$. spinosa oocysts; however, this pig was weak and sickly prior to experimental infection. Ernst (1987) did not believe that E. spinosa was pathogenic for young pigs fed up to $1 \times 10^{5}$ oocysts. Koudela and Vitovec (1992) described microscopic changes but not clinical disease in pigs experimentally infected with $5 \times 10^{5} \mathrm{E}$. spinosa oocysts. The lesions consisted of inflammatory cell infiltration in the lamina propria of the posterior jejunum, Peyer's patch activation, and sporadic erosions scattered at the villous tips. No villous atrophy was seen, but large numbers of endogenous stages were present (Koudela and Vitovec, 1992). The lesions described by these authors are much less severe than those we observed in the present study. We did not isolate Salmonella $\mathrm{sp}$. from the pig tissues we examined, but there is a chance it was present and enhanced the E. spinosa infection we observed.

\section{LITERATURE CITED}

ERnst, J. V. 1987. Pathogenicity in pigs experimentally infected with Eimeria spinosa. Journal of Parasitology 73: 1254-1256.

Greiner, E. C., C. Taylor, W. B. Frankenberger, and R. C. Belden. 1982. Coccidia of feral swine from Florida. Journal of the American Veterinary Medical Association 181: 1275-1277.

HenRY, D. P. 1931. A study of the species of Eimeria occurring in swine. University of California Publications in Zoology 36: 115126.

Hill, J. E., L. G. Lomax, D. S. Lindsay, And B. S. LynN. 1985. Coccidosis caused by Eimeria scabra in a finishing hog. Journal of the American Veterinary Medical Association 186: 981-983.

KoudelA, B., AND J. VitoveC. 1992. Biology and pathogenicity of Eimeria spinosa Henry, 1931 in experimentally infected pigs. International Journal for Parasitology 122: 651-656.

Lindsay, D. S., J. V. Ernst, W. L. Current, B. P. Stuart, and T. B. STEWART. 1984. Prevalence of oocysts of Isospora suis and Eimeria spp. from sows on farms with and without a history of neonatal coccidiosis. Journal of the American Veterinary Medical Association 185: 419-421.

Vetterling, J. M. 1965. Coccidia (Protozoa: Eimeriidae) of swine. Journal of Parasitology 51: 897-912.

1966. Prevalence of coccidia in swine from six localities in the United States. Cornell Veterinarian 56: 155-166.

WiesenhütTer, E. 1962. Ein Beitrag zur Kenntnis der endogenen Entwicklung von Eimeria spinosa des Schweines. Berliner und Müncher Tierärztliche Wochenschrift 75: 172-173. 